\title{
Encouraging the Development of New Antibiotics: Are Financial Incentives the Right Way Forward? A Systematic Review and Case Study
}

This article was published in the following Dove Press journal: Infection and Drug Resistance

\author{
Ilinca A Dutescu iD \\ Sean A Hillier (iD \\ School of Health Policy \& Management, \\ Faculty of Health, York University, \\ Toronto, ON, Canada
}

\begin{abstract}
Antibiotic resistance is an urgent public health threat that has received substantial attention from the world's leading health agencies and national governmental bodies alike. However, despite increasing rates of antibiotic resistance, pharmaceutical companies are reluctant to develop new antibiotics due to scientific, regulatory, and financial barriers. Nonetheless, only a handful of countries have addressed this by implementing or proposing financial incentive models to promote antibiotic innovation. This study is comprised of a systematic review that aimed to understand which antibiotic incentive strategies are most recommended within the literature and subsequently analyzed these incentives to determine which are most likely to sustainably revitalize the antibiotic pipeline. Through a case study of Canada, we apply our incentive analysis to the Canadian landscape to provide decisionmakers with a possible path forward. Based on our findings, we propose that Canada support the ongoing efforts of other countries by implementing a fully delinked subscription-based market entry reward. This paper seeks to spark action in Canada by shifting the national paradigm to one where antibiotic research and development is prioritized as a key element to addressing antibiotic resistance.
\end{abstract}

Keywords: antimicrobial resistance, antibiotics, health policy, financial incentives, Canada

\section{Introduction}

Antibiotics - drugs that target bacterial infections - have revolutionized modern medicine by allowing us to treat previously lethal communicable diseases. This has resulted in higher life expectancies worldwide, as people are living approximately 30 years longer than they were in the early 20th century. ${ }^{1,2}$ A century ago, communicable diseases were the leading cause of death; however, the incidence of death in this category has been on a downward trend since the commercialization of antibiotics in the 1940s. Communicable diseases have been replaced by noncommunicable diseases, such as heart disease and cancer, as top causes of death in recent decades. ${ }^{3}$ In addition to provoking a shift in mortality causes, the widespread use of antibiotics has also significantly lowered the risks associated with many medical procedures, including organ transplants, childbirth, and chemotherapy. ${ }^{4-6}$ However, the effectiveness of many antibiotics is diminishing at a concerning rate, as bacteria are becoming increasingly more resistant to the existing supply of antibiotics as a result of natural evolution, certainly, but also largely due to almost 80 years of inappropriate use. ${ }^{7}$ Inappropriate use has been prevalent from commercialization onwards, with most recent studies reporting that between $45 \%$ to $66 \%$ of
Correspondence: llinca A Dutescu York University, 4700 Keele Street, Toronto, ON, M3] IP3, Canada Tel + I 647-886-9829

Email idutescu@gmail.com
Infection and Drug Resistance 202।:|4 4|5-434 
antibiotics prescribed at the primary care level are unnecessary and that the indicated drug, dosage, or treatment duration are unsuitable in approximately 50\% of prescriptions. $^{5,8-10}$ The effects of antibiotic resistance (ABR) have already been devastating, with at least 700,000 deaths from drug-resistant infections occurring worldwide every year and experts estimating that this number will surpass 10 million deaths per year by $2050 .^{6}$ In Canada, 14,000 deaths from drug-resistant infections occurred in 2018 and 400,000 Canadians are expected to die from drug-resistant infections by $2050 .^{9}$ Notably, diminishing antibiotic effectiveness is leading to the resurgence of existing communicable disease threats and the emergence of novel ones, as illustrated by increasing prevalence of hard-to-treat multi-drug infections ${ }^{11}$ and by the ongoing COVID-19 pandemic which has motivated superfluous antibiotic prescriptions in patients hospitalized with suspected COVID-19. ${ }^{12}$

Although this problem has received significant attention in recent years, with influential agencies like the World Health Organization (WHO), the World Bank, and national governments investing significant resources into the development of action plans and surveillance systems to address ABR, little has been done in the area of encouraging the development of new antibiotic drugs in countries such as Canada. ${ }^{13,14}$ Worldwide, the antibiotic development pipeline has all but dried up, demonstrated by the fact that few antibiotics that provide a significant clinical benefit over existing drugs have been approved in the last 30 years. ${ }^{15-17}$ Rather, for many antibiotics, there are limited, if any, replacement products in development, with only 12 of 50 antibiotics in the development pipeline targeting priority Gram-negative pathogens, although these pose a great risk to humans. ${ }^{16,18,19}$ To exacerbate matters, many pharmaceutical companies are abandoning their antibiotic research and development (R\&D) programmes altogether, as seen by the exiting of 15 of the 18 largest global pharmaceutical firms from this space in the last 30 years. ${ }^{9,20}$ This concerning shift in pharmaceutical companies' ventures is due to multiple scientific, regulatory, and economic barriers associated with the development and marketing of new antibiotics.

The purpose of this article is two-fold: (1) to analyze the existing and proposed antibiotic financial incentive strategies from around the world through a systematic literature review and (2) to present a case study of Canada to propose which - if any - financial incentives could be feasibly implemented in this country to support the global effort for inducing antibiotic innovation. These objectives were realized by critically analyzing the strategies recommended by articles meeting our inclusion criteria and assessing each recommended incentive strategy for their ability to productively foster R\&D. Through a case study of Canada, we provide decision-makers with a possible path forward that could befit the Canadian landscape based on our financial incentive analysis.

\section{Background}

While scientific barriers, which consider the challenges associated with the discovery of new antibiotic molecules of clinical value, and regulatory barriers, such as the innate difficulties of meeting regulatory expectations for clinical trials involving antibiotics, are certainly significant, it has been argued that economic barriers present the biggest hurdle to antibiotic development, as this deters drug developers from investing in antibiotics at every point of the R\&D process. ${ }^{21}$

The production of new antibiotics is greatly hindered by profitability challenges which uniquely affect antibiotics. Antibiotic infections generally occur over a short period of time and then the patient is no longer in need of the drug - contrary to chronic diseases that tend to generate revenue over the span of the patient's life postdiagnosis., 9,22,23 However, while other existing shortcourse pharmaceuticals (ie, vaccines) are nonetheless profitable, the threat of $\mathrm{ABR}$ requires increased antibiotic stewardship, meaning that any new antibiotics that would be introduced into the market would be reserved for infections caused by multi-drug resistant bacterial strains for which no other effective drugs exist, thereby keeping profits low. ${ }^{21,22,24}$ Alternatively, if new antibiotics are active against multidrug-resistant bacteria for which few, if any, effective treatments exist, it is predicted that these drugs will become ineffective relatively quickly upon use as a result of ABR. Furthermore, since antibiotics of the same class typically have the same mechanism of action, resistance may develop towards a shelved product that belongs to the same class as a different drug that has higher volume sales, thereby rendering it less effective despite it being preserved. ${ }^{25}$ This problem has no easy solution, due to the fact that increasing antibiotic drug prices to combat decreased pharmaceutical profitability would only serve to exacerbate the problem, as lowerincome countries - which are disproportionally affected by $\mathrm{ABR}^{26,27}$ - require access to affordable drugs to prevent deaths due to treatable infections. ${ }^{6,28}$ Also, the prices 
of new antibiotics are generally kept low by the existence of a wide variety of inexpensive generic products that have similar clinical indications as branded products and which continue to have clinical utility. $6,17,21,22,29$

Given these multi-layered challenges and the lack of significant progress - despite strategies to address antibiotic resistance at other levels (ie, stewardship programs, awareness campaigns, surveillance, etc.) - action is needed to stimulate the R\&D of new antibiotics. In order to address ABR, we need a steady supply of new and clinically important antibiotics; therefore, a handful of antibiotics should be in development at any given time, rather than there being extremes where multiple antibiotic developments occur and then many years where they do not. ${ }^{30}$ Around the world, incentives have been implemented and numerous more are being suggested as possible options to sustainably revitalize the antibiotic pipeline to tackle the presented issues. Financial incentives that motivate investment in antibiotics by drug companies can be classified into either push or pull mechanisms, whereby push mechanisms focus on decreasing antibiotic development costs and pull mechanisms aim to increase or ensure adequate market revenue for newly approved antibiotics (further discussed in the results section). ${ }^{18,19,29,31,32}$

\section{Methods}

This research consists of two distinct methodological approaches: first we conducted a systematic literature review and secondly, building upon those results, we applied an incentive analysis to draw out our conclusions. The literature review was performed to answer the following question: should drug developers be given financial incentives to encourage the development of novel antibiotics to address the global health threat of ABR, and if so, which incentives would be most productive when applied to a Canadian case study? This systematic review was conducted in accordance with the Preferred Reporting Items for Systematic Reviews and Meta-Analyses (PRISMA) guidelines. ${ }^{33}$ On April 6, 2020 an electronic search of the following five databases was performed: Medline (Ovid), Pubmed, Embase, Web of Science (Science \& Social Science Citation Indexes), and Scopus. The medical subject headers $(\mathrm{MeSH})$ used in the search were "drug resistance, microbial" and "drug industry" and the key words used were "incentive", "award", "reward", "antibiotic", "antimicrobial", "research", and "development". Appropriate variations were used to account for word variations and plurals.
In order to be included, studies had to:

- Be published in English;

- Be published after January 2010, to correspond with rising ABR awareness in the last decade;

- Focus on the analysis or review of one or more financial incentive strategies for encouraging antibiotic R\&D;

- Be peer-reviewed or commentaries published in peerreview journals.

The literature search retrieved 2227 records. After duplicates were removed, 1098 titles and abstracts were screened, and 986 records were excluded for not conforming to the inclusion criteria. Studies were further excluded if they:

- Comprised of records consisting of letters to the editor, correspondence, or conference papers and abstracts;

- Did not specifically focus on financial incentives to promote new antibiotics or which only broadly addressed financial incentives, without offering an in-depth insight into any models or offering any incentive suggestions;

- Focused on incentives to reduce inappropriate prescriptions, improve antibiotic stewardship, improve multi-country availability of antibiotics, or promote fewer antibiotic emissions into the environment;

- Focused on the topic of scientific and/or regulatory incentives;

- Focused on financial incentives but not specifically for antibiotic agents, as ideas from other sectors have been largely considered and applied to the antibiotics landscape.

The full texts of the remaining 112 articles were assessed for eligibility by the authors, of which 70 were deemed outside the inclusion criteria. The review encompasses 42 records which were included in the final analysis (Figure 1). Notably, most of the included studies were either perspective, commentary, or review articles (88\%), which was expected for two reasons: (1) since this research question is at the policy level and cannot be tested for safety and efficacy through observation or interventional trials at the individual level, original research is scarce, and (2) the scope of this paper is to determine a recommendation for a Canadian case study based on analyzing the recommendations from existing literature pertaining to this topic; therefore, opinion articles and review articles are particularly useful. Commentaries were included because they are 


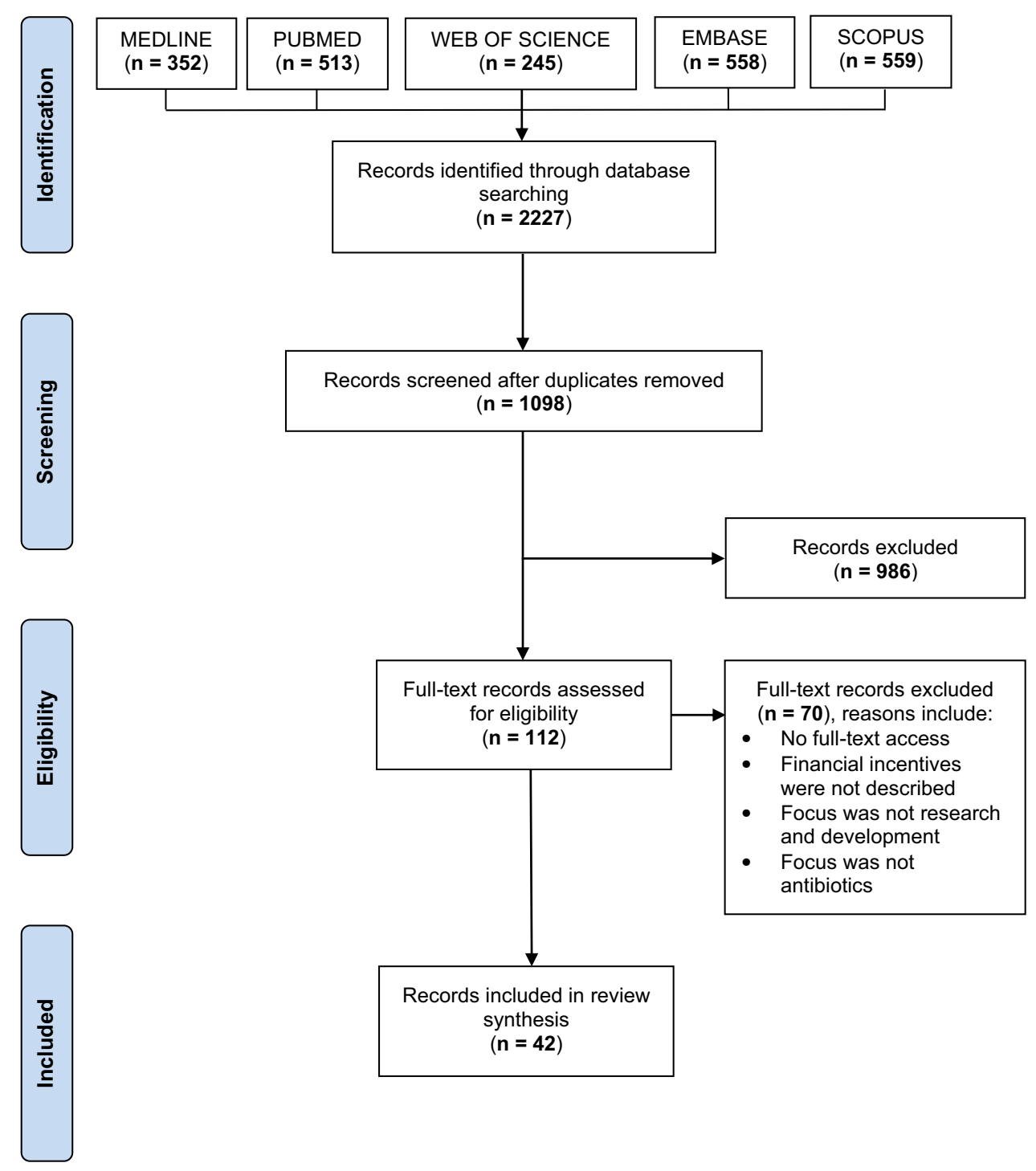

Figure I Study flowchart according to the PRISMA recommendations.

Notes: PRISMA figure adapted from Liberati A, Altman D, Tetzlaff J, et al. The PRISMA statement for reporting systematic reviews and meta-analyses of studies that evaluate health care interventions: explanation and elaboration. Journal of clinical epidemiology. 2009;62(10). Creative Commons. ${ }^{33}$

taken up in the public domain by policy experts, and are therefore valuable for understanding current international trends in this subject area. All included articles were given equal weighting as perspective and reviews represent the current academic perspective whilst commentaries are readily applicable at the policy-level. Next, the recommendations provided by the articles included in this review were critically assessed to determine which incentive strategies could be effectively implemented within a Canadian context. To this effect, article-recommended incentives were analyzed using a modified version of the assessment framework developed by Renwick et al. ${ }^{18}$ Renwick's framework consists of four market criteria for selecting an optimal incentive model:

1. Does the incentive improve the net present value (i.e., the profitability metric) for antibiotic projects?

2. Does the incentive promote small to medium-sized enterprise (SME) participation?

3. Does the incentive promote large pharmaceutical company participation?

4. Does the incentive promote cooperation and synergy among key players (i.e., industry, academia, government)? 
Besides these market criteria, Renwick's framework also evaluates whether the incentive model aligns with public health objectives, namely:

1. Does the incentive promote antibiotic stewardship?

2. Does the incentive improve patient access to antibiotics?

However, given the pull incentive pilot schemes that have been recently launched in the United Kingdom and Sweden, we modified Renwick's framework to ensure that these schemes were being taken into consideration as part of the incentive feasibility assessment. Additionally, while paying special attention to Canada as the setting for the proposed incentives, we opted to further modify Renwick's framework to add new but related assessment criteria that preserve Renwick's categories (ie, market attractiveness, public health objectives, and implementation feasibility) while providing more context, insight, and specificity to these categories. Our modified framework also assesses the following items:

1. Is the incentive strategy forecasted to entail large structural changes to the current business model in Canada?

2. Has the incentive strategy already been piloted or implemented in other countries?

3. Does the incentive strategy involve delinking the developer's return from sales volume and price?

4. Does the incentive strategy involve conditional payments based on antibiotic performance?

5. Does the incentive strategy promote or reward innovation in antibiotic R\&D projects?

To account for the heterogeneity between included articles, all article-recommended incentive strategies were subjected to the same criteria-based assessment and assigned a score between 0 and 11, with a greater score indicating a higher probability that the incentive strategy would productively increase the market value for antibiotics, be feasible to implement, and contribute to antibiotic conservation efforts. Each incentive strategy was given either a score of 1 if it met the respective criteria or a score of 0 if it did not. The total score was then calculated for each incentive strategy. While every effort was made to ensure the framework criteria and derived scores were as non-biased as possible, there is nonetheless a level of subjectiveness within the aforenoted assessment process. Bias was controlled to the extent possible by reaching consensus between authors on all scoring.

This modified framework was utilized to assign each incentive strategy recommended by the articles included in this review an individual score by which we were able to quantify the advantages and notable shortcomings each. These scores were taken into account within our wider discussion pertaining to the Canadian context and assisted us in coming up with recommendations for how Canada can work with the global community to sustainably improve the antibiotic market.

\section{Results}

Tables 1 and 2 demonstrate the characteristics of the 42 articles included in this analysis. These articles were published between 2010 and 2020 with most of the records being published in 2018 (26\%). Table 2 indicates that interest in the topic of financial incentives rose significantly in 2016, evidenced by the increase in annual publications from that year onwards compared to the years before. Interestingly, recommendation trends have remained consistent over the decade - despite changes in particular implementation models, as discussed later - with market entry reward (MER)-based incentives representing the most recommended strategy type (Table 2).

Within the 42 articles, numerous types of push and pull incentive models were identified, with many being referenced in only one to three articles, whilst others, such as grants or MERs, being referenced in most of the articles. Despite this, there are broad categories of push and pull mechanisms that these articles identified (Table 3). Pertaining to push mechanisms, research grants, subsidies from public-private partnerships, and tax incentives (ie, tax credits or tax cuts) that can be offered for any stage of the R\&D process represent the three broad categories of described mechanisms. ${ }^{18,34-36}$ Moreover, pull strategies were identified as (1) patent extensions, which delay generic drugs from entering the market; (2) MERs, which reward drugs for entering the market and fully or partially delink the product from the amount sold; and (3) tradeable vouchers, which would be given to drug companies after regulatory approval of a new high-priority drug, and can be used by the drug company to fast-track the review process, extend the patent life of another one of their compounds, or sell it to another company. 1,18,29,34,37,38 Table 3 provides a simplified overview of each of these 
Table I Characteristics of the Included Articles

\begin{tabular}{|c|c|c|c|c|c|c|}
\hline Authors, Year & $\begin{array}{l}\text { Type of } \\
\text { Article }\end{array}$ & Comparative? & $\begin{array}{l}\text { Pro Push } \\
\text { Incentives? }\end{array}$ & $\begin{array}{l}\text { Pro Pull } \\
\text { Incentives? }\end{array}$ & Recommendation? & $\begin{array}{l}\text { Enforced/ } \\
\text { Managed by? }\end{array}$ \\
\hline Årdal et $\mathrm{al}^{28} 2017$ & Perspective & Yes & Yes & Yes & $\begin{array}{l}\text { MER (partially delinked } \\
\text { model): market-price model }\end{array}$ & N/D \\
\hline Årdal et $\mathrm{al}^{49} 2018$ & Pilot study & Yes & $N / D$ & Yes & $\begin{array}{l}\text { MER (partially delinked } \\
\text { model) }\end{array}$ & Government \\
\hline Baraldi et al $\left.\right|^{34} 2016$ & $\begin{array}{l}\text { Qualitative } \\
\text { study } \\
\text { (interviews) }\end{array}$ & Yes & $N / D$ & N/D & $N / D$ & N/D \\
\hline Batista et al ${ }^{19} 2019$ & Review & Yes & Yes & Yes & $N / D$ & Multi-national (EU) \\
\hline Bhatti et al 2018 & Perspective & No & Yes & Yes & Mix/hybrid; tax credits, MER & Government \\
\hline Brogan et $\mathrm{al}^{22} 2013$ & Perspective & No & Yes & Yes & Mix/hybrid; OMA model & $\begin{array}{l}\text { NGO Government } \\
\text { Multi-national (EU) }\end{array}$ \\
\hline Brogan et $\mathrm{al}^{36} 2016$ & Perspective & No & Yes & Yes & Mix/hybrid; OMA model & $\begin{array}{l}\text { NGO Government } \\
\text { Multi-national }\end{array}$ \\
\hline Brogan et a $\left.\right|^{52} 2016$ & Commentary & No & Yes & Yes & $\begin{array}{l}\text { Mix/hybrid; early-stage push } \\
\text { funding, OMA model }\end{array}$ & Multi-national (G20) \\
\hline Ciabuschi et al $\left.\right|^{31} 2019$ & $\begin{array}{l}\text { Simulation } \\
\text { study }\end{array}$ & Yes & Yes & Yes & $\begin{array}{l}\text { Mix/hybrid; grants for SMEs, } \\
\text { MERs for large } \\
\text { pharmaceutical companies }\end{array}$ & $N / D$ \\
\hline Daniel et al ${ }^{50} 2017$ & Perspective & Yes & Yes & Yes & MER (PAVE award) & PPPs \\
\hline Daniel et $\mathrm{al}^{39} 2018$ & Perspective & Yes & $N / D$ & Yes & MER (PAVE award) & $\begin{array}{l}\text { PPPs (PAVE award is } \\
\text { paid by insurance } \\
\text { companies) }\end{array}$ \\
\hline Darrow et $\mathrm{al}^{23} 2018$ & Review & Yes & Yes & Yes & $\begin{array}{l}\text { Mix/hybrid; grants in early } \\
\text { stages of research, advance } \\
\text { market commitments }\end{array}$ & $\begin{array}{l}\text { NGO } \\
\text { PPPs } \\
\text { Global coordination }\end{array}$ \\
\hline Hojgard ${ }^{40} 2012$ & Review & Yes & Yes & $N / D$ & $\begin{array}{l}\text { Subsidise R\&D costs, levied } \\
\text { fee on antibiotic use }\end{array}$ & $\begin{array}{l}\text { Multi-national } \\
(\mathrm{WHO}) \\
\text { Government }\end{array}$ \\
\hline Hollis et $\mathrm{al}^{25} 2015$ & Perspective & No & $N / D$ & Yes & $\begin{array}{l}\text { MER (de-linkage models), } \\
\text { Pigouvian tax on non-human } \\
\text { antibiotic use }\end{array}$ & $\begin{array}{l}\text { Global coordination } \\
\text { Governments }\end{array}$ \\
\hline James $^{62} 2018$ & Perspective & No & No & No & $\begin{array}{l}\text { Does not support financial } \\
\text { incentives }\end{array}$ & $\begin{array}{l}\text { Global infrastructure } \\
\text { to address antibiotic } \\
\text { resistance }\end{array}$ \\
\hline Kesselheim et al ${ }^{41} 2010$ & Perspective & Yes & Yes & Yes & $\begin{array}{l}\text { Conservation-based market } \\
\text { exclusivity }\end{array}$ & N/D \\
\hline
\end{tabular}

(Continued) 
Table I (Continued).

\begin{tabular}{|c|c|c|c|c|c|c|}
\hline Authors, Year & $\begin{array}{l}\text { Type of } \\
\text { Article }\end{array}$ & Comparative? & $\begin{array}{l}\text { Pro Push } \\
\text { Incentives? }\end{array}$ & $\begin{array}{l}\text { Pro Pull } \\
\text { Incentives? }\end{array}$ & Recommendation? & $\begin{array}{l}\text { Enforced/ } \\
\text { Managed by? }\end{array}$ \\
\hline $\begin{array}{l}\text { Kesselheim et al }{ }^{42} \\
201 \mathrm{I}\end{array}$ & Review & Yes & Yes & Yes & $\begin{array}{l}\text { Mix/hybrid ACE program; } \\
\text { MER, value-based } \\
\text { reimbursements (eg, } \\
\text { advance market } \\
\text { commitments), } \\
\text { conservation-based market } \\
\text { exclusivity, grants }\end{array}$ & $\begin{array}{l}\text { PPPs } \\
\text { Government }\end{array}$ \\
\hline $\begin{array}{l}\text { Laxminarayan et } \mathrm{al}^{43} \\
201 \mathrm{I}\end{array}$ & Perspective & Yes & No & Yes & $\begin{array}{l}\text { Conservation-based market } \\
\text { exclusivity }\end{array}$ & PPPs \\
\hline Livermore $^{53} 2018$ & Perspective & No & Yes & No & $\begin{array}{l}\text { Push incentives: reducing } \\
\text { developmental costs and } \\
\text { barriers to market-entry }\end{array}$ & $\begin{array}{l}\text { Government/ } \\
\text { regulatory bodies }\end{array}$ \\
\hline Luepke et $\mathrm{al}^{29} 2017$ & Review & Yes & Yes & Yes & Mix/hybrid & Global coordination \\
\hline Lum et $\mathrm{al}^{54} 2018$ & Perspective & No & $N / D$ & Yes & $\begin{array}{l}\text { Diagnosis confirmation } \\
\text { model for the hospital } \\
\text { setting, value-based } \\
\text { reimbursements, MER }\end{array}$ & $\begin{array}{l}\text { Government } \\
\text { PPPs }\end{array}$ \\
\hline Mckellar et al ${ }^{44} 2014$ & Perspective & Yes & No & Yes & Increase antibiotic prices & N/D \\
\hline Morel et al ${ }^{38} 2018$ & Commentary & Yes & $N / D$ & Yes & $\begin{array}{l}\text { MER (fully delinked } \\
\text { approach) }\end{array}$ & Global coordination \\
\hline Okhravi et al ${ }^{45} 2018$ & $\begin{array}{l}\text { Simulation } \\
\text { study }\end{array}$ & Yes & $N / D$ & Yes & MER & N/D \\
\hline $\begin{array}{l}\text { Outterson et al }{ }^{17} \\
2015\end{array}$ & Review & No & N/D & Yes & MER & Multi-national \\
\hline $\begin{array}{l}\text { Outterson et al }{ }^{55} \\
2020\end{array}$ & Review & No & $N / D$ & Yes & MER & $\begin{array}{l}\text { Multi-national } \\
\text { PPPs (specifically, } \\
\text { public benefit } \\
\text { corporations) }\end{array}$ \\
\hline Renwick et al ${ }^{18} 2016$ & Review & Yes & Yes & Yes & $\begin{array}{l}\text { Mix/hybrid; I-2 push } \\
\text { incentives and I large pull } \\
\text { incentive }\end{array}$ & Government \\
\hline Renwick et $\mathrm{al}^{21} 2018$ & Perspective & No & Yes & Yes & $\begin{array}{l}\text { Mix/hybrid; expand late- } \\
\text { stage push funding of clinical } \\
\text { trials, implement a global } \\
\text { pull mechanism (MER or } \\
\text { OMA) }\end{array}$ & $\begin{array}{l}\text { Multi-national } \\
\text { Government } \\
\text { NGOs }\end{array}$ \\
\hline Rex et $\mathrm{al}^{56} 2016$ & Perspective & No & N/D & Yes & $\begin{array}{l}\text { MER (fully delinked } \\
\text { approach based on bench- } \\
\text { marked payments) }\end{array}$ & Multi-national \\
\hline Rome et al 2019 & $\begin{array}{l}\text { Simulation } \\
\text { study }\end{array}$ & No & $N / D$ & N/D & N/D & N/D \\
\hline
\end{tabular}

(Continued) 
Table I (Continued).

\begin{tabular}{|c|c|c|c|c|c|c|}
\hline Authors, Year & $\begin{array}{l}\text { Type of } \\
\text { Article }\end{array}$ & Comparative? & $\begin{array}{l}\text { Pro Push } \\
\text { Incentives? }\end{array}$ & $\begin{array}{l}\text { Pro Pull } \\
\text { Incentives? }\end{array}$ & Recommendation? & $\begin{array}{l}\text { Enforced/ } \\
\text { Managed by? }\end{array}$ \\
\hline Savic et a $\left.\right|^{35} 2018$ & Review & No & Yes & N/D & $\begin{array}{l}\text { Grants that are more } \\
\text { targeted and effective }\end{array}$ & Pipeline coordinator \\
\hline Sciarretta et $\mathrm{al}^{37} 2016$ & Review & Yes & Yes & Yes & $\begin{array}{l}\text { Mix/hybrid; MER (de-linkage } \\
\text { models) }\end{array}$ & $\begin{array}{l}\text { Global pull } \\
\text { mechanism }\end{array}$ \\
\hline Simpkin et al ${ }^{46} 2017$ & Review & Yes & Yes & Yes & $\begin{array}{l}\text { Mix/hybrid; late-stage push } \\
\text { funding, tax incentives, } \\
\text { value-based } \\
\text { reimbursements, advanced } \\
\text { market commitments, MER } \\
\text { (with bonuses for meeting } \\
\text { clinical goals) }\end{array}$ & $\begin{array}{l}\text { Multi-national } \\
\text { Government }\end{array}$ \\
\hline Singer et $\mathrm{al}^{57} 2019$ & Perspective & No & Yes & Yes & $\begin{array}{l}\text { Mix/hybrid; open-source } \\
\text { drug development }\end{array}$ & $\begin{array}{l}\text { Multi-national } \\
\text { PPPs }\end{array}$ \\
\hline Sinha et al' 2016 & Review & No & Yes & No & Early-stage push funding & N/D \\
\hline So et $\mathrm{al}^{32} 2014$ & Review & No & Yes & Yes & $\begin{array}{l}\text { Mix/hybrid; OSDD initiative } \\
\text { (Indian pilot business model; } \\
\text { shared resources, with drug } \\
\text { leads tested in publicly } \\
\text { funded clinical trials and } \\
\text { marketed as generic drugs) }\end{array}$ & PPPs \\
\hline Spellberg $^{58} 2014$ & Review & No & Yes & No & Grants & PPPs \\
\hline Talbot et al ${ }^{20} 2019$ & Review & No & Yes & Yes & Mix/hybrid & $N / D$ \\
\hline $\begin{array}{l}\text { Theuretzbacher et a }\left.\right|^{59} \\
2017\end{array}$ & Review & No & $N / D$ & Yes & $\begin{array}{l}\text { MER (based on clinical } \\
\text { value) }\end{array}$ & Global collaboration \\
\hline Towse et al ${ }^{48} 2011$ & Review & Yes & Yes & Yes & $\begin{array}{l}\text { Pull incentives: MER, higher } \\
\text { antibiotic prices }\end{array}$ & N/D \\
\hline Towse et $\mathrm{al}^{47} 2017$ & Perspective & Yes & N/D & Yes & $\begin{array}{l}\text { MER (partially delinked } \\
\text { model) - insurance model }\end{array}$ & Healthcare system \\
\hline Vågsholm et $\mathrm{al}^{60} 2010$ & Perspective & No & $N / D$ & $N / D$ & Pigouvian tax & Multi-national \\
\hline
\end{tabular}

Abbreviations: MER, market entry reward; OMA, options market award; NGO, non-governmental organizations; PAVE, priority antimicrobial value and entry; PPPs, public-private partnerships; ACE, antibiotic conservation and effectiveness; OSDD, open-source drug discovery.

incentive strategies as well as their associated advantages and disadvantages, reflecting our literature findings. Importantly, this table describes incentives based on the general characteristics of the type of incentive strategy, which inherently overlooks differences between the characteristics of actual policies representing a strategy type that have been implemented.

Of the 42 articles included for analysis, 21 compared two or more incentive models to determine which one(s) were superior to the others. ${ }^{18,19,23,28,29,31,34,37-50}$ Thirty- eight articles recommended a particular push ince ntive, pull incentive, or a push-pull hybrid model. ${ }^{1,17,18,20-23,25,28,29,31,32,35-60}$ In terms of the four that did not make a recommendation, two of the studies simply reviewed different incentives and outlined possible benefits and disadvantages of each without offering a final recommendation, ${ }^{19,34}$ one focused on analyzing the disadvantages associated with exclusivity extension pull strategies, ${ }^{61}$ and the last paper did not support any push or pull financial incentives. ${ }^{62}$ 
Table 2 Trends Pertaining to Financial Incentive Models for Antibiotic Innovation in the Literature Between 2010 and 2020

\begin{tabular}{|l|l|l|}
\hline $\begin{array}{l}\text { Publication } \\
\text { Year }\end{array}$ & $\begin{array}{l}\text { Number of } \\
\text { Publications }\end{array}$ & $\begin{array}{l}\text { Most Popular } \\
\text { Recommendation }\end{array}$ \\
\hline 2010 & 2 & X \\
2011 & 3 & Pull incentives \\
2012 & 1 & Pull incentives \\
2013 & 1 & Mix/hybrid \\
2014 & 3 & X \\
2015 & 2 & MER \\
2016 & 7 & Mix/hybrid \\
2017 & 6 & MER \\
2018 & 11 & MER \\
2019 & 5 & Mix/hybrid \\
2020 & 1 & MER \\
\hline
\end{tabular}

Note: $X=$ No majority in respective year. Abbreviation: MER, market entry reward.

\section{Mix/Hybrid Models}

The incentive strategy that was the most recommended among the included articles was a mix/hybrid model, suggested by 15 articles. ${ }^{18,20-23,29,31,32,36,37,42,46,51,52,57}$ However, there was no consensus among authors on what a hybrid model should or could look like. The specific push and pull components varied from one article to the next, with many of the articles not specifying which particular push or pull incentives they would suggest for the model (Table 1). Nonetheless, the most recommended hybrid model among these articles was the Options Market Award (OMA) model, with four studies suggesting it as the optimal approach. ${ }^{21,22,36,52}$ The OMA model uniquely combines aspects of both push and pull mechanisms into one model, whereby interested stakeholders may purchase an "option" to buy a set volume of an antibiotic at a discounted price to be redeemed if and when the antibiotic drug is marketed. ${ }^{22}$ The earlier the options are purchased, the lower its price but the greater the risk of the antibiotic not making it to market. ${ }^{22}$ Another hybrid model, known as the Antibiotic Conservativeness and Effectiveness (ACE) model, was described by Kesselheim and Outterson, ${ }^{42}$ whereby the value of MER payments is determined by the level of success that the antibiotic has in meeting conservation targets. A distinctive feature of the ACE model is that it is proposed as a voluntary program that antibiotic manufacturers or sponsors can choose to opt-out of after market approval. ${ }^{42}$ Interestingly, five of the 15 articles suggesting a mix/hybrid model included an
MER as one of the components for their suggested model. ${ }^{31,37,42,46,51,52}$

Other components of recommended mix/hybrid models consisted of research grants, ${ }^{21,23,31,42,46,52}$ advance market commitments, ${ }^{23,42,46}$ tax credits, ${ }^{51}$ conservation-based market exclusivity, ${ }^{42}$ and open-source drug development. $^{32,57}$ Three articles did not elaborate on the characteristics of their proposed mix/hybrid models, focusing instead on advocating for the strengths of concurrently implementing multiple mechanisms as opposed to just one on a general level. ${ }^{18,20,29}$

\section{Market Entry Award Models}

The second most popular suggestion among the articles was an MER, with 14 articles recommending this pull mechanism. ${ }^{17,25,28,38,39,45,47-50,54-56,59}$ Articles outlining how the MER should be implemented, awarded, and distributed varied widely in their proposed approaches, with model differences being observed between the eligibility criteria for marketed antibiotics, the value of award payments, the extent of disruptiveness to existing market systems, and whether or not they are concerned with promoting antibiotic stewardship.

Five articles suggested a partially delinked MER model, whereby conventional volume-sale revenues are topped up through annual payments. ${ }^{28,39,47,49,50}$ These articles posited that a partially delinked MER model has the advantage of being minimally disruptive, since it would be implementable within current systems and would avoid the need for law changes associated with other proposed models. ${ }^{28,49}$ Ardal et al $^{49}$ suggested that the value of the MER should be established on a case-by-case basis, according to a predefined criteria for antibiotics. Daniel et $\mathrm{al}^{39,50}$ took this one step further, by advocating that financial awards should only be given for novel antibiotics that target the highest-priority pathogens, an idea that has been previously suggested in reports such as the Chatham House Report ${ }^{63}$ and O'Neill's Review on Antimicrobial Resistance. $^{6}$ In addition, Daniel et al ${ }^{39,50}$ argued that the MER model needs to encourage antibiotic stewardship, therefore suggesting that MER payments should require drug manufacturers to negotiate value-based contracts (ie, where payments are dependent on the "value" of the antibiotic to society) with insurers. In this model, known as the Priority Antimicrobial Value and Entry (PAVE) award model, the MER would provide drug manufacturers with the majority of the annual revenue in the first year 
Table 3 Characterizing the Advantages and Disadvantages of Financial Incentives for Antibiotic R\&D

\begin{tabular}{|c|c|c|c|}
\hline $\begin{array}{l}\text { Incentive } \\
\text { Strategy }\end{array}$ & $\begin{array}{l}\text { Policy } \\
\text { Examples }\end{array}$ & Advantages & Disadvantages \\
\hline \multicolumn{4}{|l|}{ Push Incentives } \\
\hline Grants & $\begin{array}{l}\text { JPIAMR } \\
\text { CARB-X } \\
\text { ND4BB } \\
\text { BARDA } \\
\text { NIH } \\
\text { MRC }\end{array}$ & $\begin{array}{l}\text { - Lowers cost for R\&D which will promote } \\
\text { antibiotic innovation } \\
\text { - Funds projects which SMEs may lack the } \\
\text { capital reserve to otherwise pursue } \\
\text { - Create temporary jobs for scientists } \\
35\end{array}$ & $\begin{array}{l}\text { - Risk of funding a project that ultimately will fail }{ }^{18} \\
\text { - SMEs may not be motivated to apply due to the belief that } \\
\text { they will not get them }{ }^{34}\end{array}$ \\
\hline Subsidies & - & $\begin{array}{l}\text { - Lowers company cost for R\&D which will } \\
\text { promote antibiotic innovation }{ }^{52}\end{array}$ & $\begin{array}{l}\text { - Large amounts of public funding given to pharmaceutical } \\
\text { companies may produce negative public opinion }{ }^{34} \\
\text { - Only companies that already have potential candidates } \\
\text { would be attracted by subsidies; if no candidates exist, they } \\
\text { are not likely to start R\&D from scratch }{ }^{34}\end{array}$ \\
\hline Tax incentives & READI Act & $\begin{array}{l}\text { - Easily implemented by the government }{ }^{18} \\
\text { - Market dictates which investments are } \\
\text { profitable }^{18}\end{array}$ & $\begin{array}{l}\text { - If only tax credits, not useful for SMEs because they do not } \\
\text { help cash flow } \\
\text { - Negative public opinion on tax breaks for pharmaceutical } \\
\text { companies }^{34}\end{array}$ \\
\hline \multicolumn{4}{|l|}{ Pull Incentives } \\
\hline $\begin{array}{l}\text { Advance market } \\
\text { commitments }\end{array}$ & - & $\begin{array}{l}\text { - Only rewards successful antibiotics } \\
\text { - Lowers manufacturing risk } \\
\text { - Do not require major regulatory or law } \\
\text { changes }^{18}\end{array}$ & $\begin{array}{l}\text { - Difficult to pre-determine drug specifications }{ }^{18} \\
\text { - Require upfront commitment from investors }{ }^{48} \\
\text { - Incentive to maximize sales remains }\end{array}$ \\
\hline $\begin{array}{l}\text { Exclusivity/patent } \\
\text { extensions }\end{array}$ & GAIN & $\begin{array}{l}\text { - Drug companies will have a longer time to } \\
\text { recuperate R\&D costs post-market }{ }^{18} \\
\text { - Higher drug cost may discourage overuse }{ }^{18}\end{array}$ & $\begin{array}{l}\text { - Resistance to the antibiotic could occur during period of } \\
\text { patent extension which would decrease incentive value }{ }^{37} \\
\text { - Do not reduce level of risk of investment in early R }\end{array}$ \\
\hline $\begin{array}{l}\text { \&D phases } \\
\text { - Reduced access to } \\
\text { drugs due to high } \\
\text { drug prices }{ }^{19} \\
\text { Market entry } \\
\text { reward (fully } \\
\text { delinked) }\end{array}$ & UK Pilot & $\begin{array}{l}\text { - Only rewards successful antibiotics }{ }^{18} \\
\text { - Drug conservation is ensured since the } \\
\text { product will not be sold by the developing } \\
\text { company }^{37} \\
\text { - Guaranteed revenue }{ }^{37}\end{array}$ & $\begin{array}{l}\text { - Requires a substantial amount of funding to generate } \\
\text { sustainable impact } \\
\text { - Challenging to implement } \\
\text { - Global coordination needed to ensure access to the drug } \\
\text { and to conserve use }{ }^{37} \\
\text { - Implementation needs to be tailored to national } \\
\text { circumstances }\end{array}$ \\
\hline $\begin{array}{l}\text { Market entry } \\
\text { reward (partially } \\
\text { delinked) }\end{array}$ & $\begin{array}{l}\text { Swedish } \\
\text { Pilot }\end{array}$ & $\begin{array}{l}\text { - Only rewards successful antibiotics }{ }^{18} \\
\text { - More feasible to implement than a fully } \\
\text { delinked market entry reward model }{ }^{37}\end{array}$ & $\begin{array}{l}\text { - Requires a substantial amount of funding to generate } \\
\text { sustainable impact }{ }^{37} \\
\text { - Some incentive to maximize sales remains }{ }^{38}\end{array}$ \\
\hline Tradeable vouchers & $\begin{array}{l}\text { REVAMP } \\
\text { Act }\end{array}$ & $\begin{array}{l}\text { - Only rewards successful antibiotics } \\
\text { - Do not require direct funding from the } \\
\text { government, which may make } \\
\text { implementation easier } \\
\text { - Commercial value of the voucher } \\
\text { incentivizes the development of antibiotics' }\end{array}$ & $\begin{array}{l}\text { - Does not effectively incentivize early-stage antibiotic } \\
\text { development } \\
\text { - Implementation will differ in each country }{ }^{37} \\
\text { - High cost on health system in the future due to generic } \\
\text { drugs being prohibited for longer (for wildcard vouchers) }\end{array}$ \\
\hline
\end{tabular}

Abbreviations: JPIAMR, Joint Programming Initiative on Antimicrobial Resistance (global); CARB-X, Combating Antibiotic Resistant Bacteria Biopharmaceutical Accelerator (global), ND4BB, New Drugs for Bad Bugs (European Union); BARDA, Biomedical Advanced Research and Development Authority (U.S.); NIH, National Institutes of Health (U.S.); MRC, Medical Research Council (U.K.); READI Act, Reinvigoratingl; Antibiotic and Diagnostic Innovation Act (U.S.); GAIN, Generating Antibiotic Incentives Now (U.S.); REVAMP Act, ReValuing Anti-Microbial Products Act (U.S.); R\&D, research and development; SMEs, small-medium enterprises. 
post-market approval and this revenue would subsequently decline over the remaining years of the five-year PAVE award period. ${ }^{39,50}$ Lastly, Towse et $\mathrm{al}^{47}$ offered another take on a partially delinked model, suggesting that the payment should be based on an insurance model whereby the government or healthcare system pays an annual fee to access and use the antibiotic.

On the other hand, two articles disagreed that a partially delinked option represents the optimal MER model, advocating for a fully delinked MER incentive instead. $^{38,56}$ These articles argued that the advantages of fully delinked models pertaining to ensuring long-term sustainable use trump the benefits of partially delinked models, as the former ensure that manufacturers no longer have incentive to increase unit prices to maximize sales whereas the latter do not. ${ }^{38}$ Although Morel and Edwards ${ }^{38}$ did not provide suggestions pertaining to how such models should be implemented, Rex and Outterson ${ }^{56}$ recommended that these awards should be paid out to manufactures annually for a period of five years, with payment values being higher for antibiotics meeting one or more of the following criteria: a novel mechanism of action, addressing unmet clinical needs, targeting highpriority pathogens, and/or providing a cost-advantage over existing agents.

The remaining seven articles did not elaborate on the characteristics of their proposed MER models, endorsing delinkage models on a general level instead. ${ }^{17,25,45,48,54,55,59}$ The general consensus among these articles seemed to be that there is a need for studies that pilot different MER models to determine which types hold the most promise. ${ }^{45}$

\section{Other Incentive Models}

Finally, 10 articles recommended other push or pull mechanisms, including targeted research grants or R\&D subsidies, ${ }^{1,35,53,58}$ taxing antibiotic use, ${ }^{25,40,60}$ reimbursement reforms, ${ }^{41}$ conservation-based market exclusivity, ${ }^{41,43}$ and antibiotic price increases. ${ }^{44}$

It is worth noting that while other incentive mechanisms beyond the ones mentioned above exist and may have promising qualities, the aim of this review was to ascertain which financial incentives for antibiotics are currently being recommended within the literature and to subsequently determine their usefulness according to set criteria. Therefore, incentives not recommended by any of the included articles fell outside the scope of this review.

\section{Global versus National Managing Body}

Regardless of which types of financial incentive mechanisms are implemented, a managing body that determines eligibility criteria for new antibiotics and distributes these incentives to manufacturers must be determined. However, akin to the diversity among articles concerning incentive model recommendations, the included articles also varied widely in their suggestions of how and by whom proposed incentives should be enforced and managed. Some articles had completely opposing views, with 11 articles ${ }^{17,19,29,37,38,52,55-57,59,60}$ arguing that incentives must be globally coordinated and enforced by a multi-national body, while six articles $^{18,47,49,51,53,54}$ suggested that appropriate incentives need to be determined at a national level and enforced by domestic governments. In contrast, seven articles $^{21-23,25,36,40,46}$ recommended that multiple systems should be involved in the implementation of financial incentives. For example, Brogan and Mossialos ${ }^{36}$ recommended their OMA model, envisioning it to be open to nongovernmental organizations, government, or multi-national investors to purchase options for antibiotics in clinical development; therefore, this model would engage different systems in administering financial incentive payments to manufacturing and pharmaceutical companies. Alternatively, Renwick and Mossialos $^{21}$ suggested that a global governing body should be established to mobilize and coordinate action and that this should be coupled with national investment from governments to fund antibiotic R\&D. Relatedly, five articles were less concerned with whether incentives will be managed nationally or multi-nationally, advocating instead for the need to engage both the industry and the state and thereby recommending public-private partnerships (PPPs). ${ }^{32,39,43,50,58}$ Ten articles did not provide any information, perspective, or suggestions pertaining to how a financial incentive for antibiotics should be administered. ${ }^{1,20,28,31,34,41,44,45,48,61}$

\section{Incentive Analysis}

For all incentive strategies recommended by one or more of the articles, Table 4 depicts our incentive assessment based on market attractiveness, public health objectives, and feasibility of incentive implementation. In total, we ranked three push incentive strategies (open-source drug discovery, grants, and tax incentives), seven pull incentive strategies (conservation-based market exclusivity, diagnosis confirmation model, antibiotic use fees, increased antibiotic prices, fully delinked MER, partially delinked MER, and value-based reimbursement) and two hybrid models 
(OMA and ACE). Importantly, this table is not comprehensive as other incentive models exist or have been proposed; however, this analysis is focused on the recommended incentives from articles meeting our search inclusion criteria. Applying the modified Renwick framework ${ }^{18}$ coupled with our scoring strategy, the fully delinked MER incentive strategy scored 6, the highest among all incentives, with partially delinked MERs, value-based reimbursements, the OMA model, and the ACE model all tied in second place with a score of 5 . The majority of the remaining incentive strategies had a score of 4 , including all three push incentives, as well as the conservation-based market exclusivity pull strategy and the increasing antibiotic prices strategy. The lowest-scoring incentive strategies were the fee on antibiotic use, with 3 points, and the diagnosis confirmation model, with only 1 point.

The criterium that was unmet by most of the incentive strategies included in this assessment was the "promotes cooperation and synergy among key players" criterium, with only one incentive strategy (open-source drug discovery) scoring in this area. Other criteria with limited uptake on the assessment included the antibiotic conservation criteria (ie, "involves delinking" criterium and "conditional grants/payments" criterium), with only two incentives meeting each individual criterium within this category.

\section{Discussion}

The topic of financial incentives for antibiotic development has only recently become of interest to researchers and policymakers, as evidenced by the low number of records published on this topic between 2010 to 2015, with interest rising from 2016 onwards (Table 2), likely due to the publication of the World Health Organization's Global Action Plan for addressing antimicrobial resistance in 2015. In this systematic review, it was found that there is consensus within the literature regarding the gravity of the problem of antibiotic resistance, with articles on the topic of antibiotic financial incentives agreeing that ABR rates are rising faster than the rate of production of clinically important antibiotic drugs. Included articles also generally agreed that although push incentives are necessary, a substantial pull incentive or hybrid model will be needed to tackle this complex issue. However, when it comes to what the optimal pull or incentive model should look like, there is no consensus in the literature, with diverging opinions on whether a national or international incentive strategy would be more effective in motivating the development of new antibiotics. Generally, the recommendations from the articles varied widely, as even the articles which recommended the same incentive mechanism (ie, push, pull, or a hybrid push-pull mechanism) still differed in regard to the suggested implementation approach, the managing body, the types of antibiotics which would qualify for the incentive, and whether the incentive would be a one-time payment or split-payments administered over a number of years.

There were 38 articles that supported financial incentives as promising for addressing the lack of new antibiotics being approved for use on a global scale. These articles agreed that while scientific and regulatory barriers to antibiotic innovation contribute to the lack of progress in new treatment options for hard-to-treat bacterial infections, the unattractive antibiotic market is the true hindrance for drug developers. Specifically, the fact that generic antibiotics that are capable of treating most common infections remain widely available coupled with the development of resistance occurring as soon as new antibiotics are clinically used unfortunately renders most antibiotics unprofitable. In order to stimulate impactful progress to ensure that future alternative treatments exist for even the most resistant pathogens - even if ABR rates keep rising - financial incentives must be implemented.

However, not all included articles endorsed financial incentives as promising solutions to the ABR problem. In particular, James ${ }^{62}$ did not agree that a financial incentive of any kind was an appropriate way of combating ABR, arguing that any publicly-financed incentives will only encourage the development of marginally improved antibiotics, rather than truly innovative products. As a result, publicly financed incentives would have little overall clinical benefit to tackling antibiotic resistance. James ${ }^{62}$ argues that since the public sector has limited resources, those resources would be better spent in creating a new international coordinating body that operates through publicprivate partnerships to overcome the antibiotic resistance challenges. James ${ }^{62}$ also argues that the market works best when it is left to operate freely, possibly implying that pharmaceutical companies will respond to the need of new anti-bacterial therapies when there is truly an immediate need for more solutions. However, while James ${ }^{62}$ proposal for a global coordinating infrastructure to oversee the management of antibiotic resistance - regarding both R\&D and antibiotic stewardship - is a valid recommendation, other parts of this argument overlook matters that consequently weaken the author's position. For instance, 
the antibiotic market cannot operate freely due to the need to restrict the use of marketed antibiotics to preserve their effectiveness; therefore, the regulations imposed on antibiotic development and distribution inherently distort the market. $^{21}$ Also, as it takes between 10 to 15 years for a new antibiotic to progress through the antimicrobial development pipeline, ${ }^{6,31}$ there will be a significant lag in response time from when existing antibiotics will entirely lose their effectiveness to when new, effective anti-bacterial therapies will be introduced into the market. This lag time will result in hundreds of thousands of deaths, which could be prevented by acting now - through incentives, if need be - rather than waiting for the market to necessitate action. In addition, while it is certainly true that the public sector works within a budget and that there are other causes that require public funding, it is relevant to point out that governments in developed countries tend to have more money than many corporations - however, governmental budgets are constrained due to other priorities. ${ }^{64,65}$ Nonetheless, the percentage of publicfinancing of $R \& D$ incentives could vary depending on the nation, with higher percentages of funds coming from private sources through public-private partnerships in certain countries.

Besides James, ${ }^{62}$ three other articles did not recommend any particular financial incentive model. Instead, one article solely focused on potential obstacles to implementation pertaining to different incentive mechanisms, identifying which mechanisms would be attractive or unattractive to not-for-profit research institutes, SMEs, or large pharmaceutical companies. ${ }^{34}$ Another article exclusively focused on the potential negative economic effects of market exclusivity extensions, noting that such incentive strategies are quite costly and are not evidenced to particularly reward drug innovativeness or clinical value. ${ }^{61}$ Similarly, Batista et al ${ }^{19}$ concentrated on intellectual property-based incentives, providing a thorough analysis of the theoretical advantages (eg, longer exclusivities could encourage patent-holders to preserve the effectiveness of their antibiotic drugs for longer) and empirical challenges or disadvantages (eg, the extra cost associated with transferable exclusivity incentives would be unfairly borne by patients) pertaining to such mechanisms. In these articles, the reason behind the lack of final financial incentive recommendation is unclear; however, it is possible that this was simply outside the scope of their analyses. Alternatively, it should be considered that these articles may have refrained from recommending a model because they do not believe that any particular financial incentive strategy would be useful in motivating the development of clinically beneficial antibiotics. We argue, however, that if this were the case, this perspective would be indicated and discussed within the articles; yet, neither of these three articles contain such arguments.

Our incentive analysis revealed that while different push incentive strategies each have their own specific set of strengths and weaknesses, they all appear to be moderately productive in motivating change, as all were tied with a total score of 4 points each. The strengths of push incentives lie in their tendency to be more readily implementable than pull or hybrid incentive models coupled with their ability to encourage the participation of SMEs. ${ }^{18,21,66}$ As push incentives of various types and sizes have already been implemented to motivate antibiotic R\&D in many countries, they are relatively familiar, politically palatable, and cost-effective compared to many pull incentives, thereby facilitating implementation. ${ }^{21,66}$ In addition, push incentives benefit SMEs by providing them with the funding they need for investing in new antibiotic projects or completing expensive later-stage clinical trials. $^{18,48,67}$ However, such incentives are less likely to motivate large pharmaceutical firms to resume R\&D in antibiotics if they have already abandoned this field. Additionally, push incentives do little in supporting public health goals such as antibiotic conservation, rewarding innovation, or improving patient access to antibiotics, as they are typically not tied to any post-approval conditions. ${ }^{67}$ Therefore, we support the consensus in the literature that push incentives alone are not sufficient for addressing the antibiotic innovation problem; however, they are nonetheless a good place to start. Overall, our literature findings and assessments suggest that push incentives will be most productive when applied in conjunction with one or more pull incentives.

Interestingly, a much wider scoring variability was observed for pull incentive strategies, with both the lowest score and the highest score being awarded to strategies within this category. A commonality between all the pull incentives evaluated in this review was that none would be particularly helpful in encouraging the participation of SMEs; however, the majority of pull strategies are forecasted to encourage the participation of large pharmaceutical companies with access to $R \& D$ capital reserves instead. ${ }^{18,63}$ Moreover, most pull incentives are projected to have challenges pertaining to their implementation feasibility, as the majority would require significant change to 
the current business model and many have not yet been implemented in other countries. However, this could be subject to change given that a couple pilot projects are currently underway that may soon redefine how we view the implementation feasibility of pull incentives, if they are successful.

In the United Kingdom (UK), the National Institute for Health and Care Excellence (NICE) and the National Health Service (NHS) of England have begun to implement a pilot project that plans to use a hybrid subscription model to reimburse pharmaceutical companies for antimicrobial drug development. ${ }^{68,69}$ This subscription model combines a value-based reimbursement with a fullydelinked MER, with antibiotics being subjected to a health technology assessment that is to be conducted by NICE to determine the clinical value of the antibiotic in question. ${ }^{69}$ Suppliers of antibiotics which pass this assessment will be reimbursed on the basis of a multiyear contract paid in yearly installments, with the antibiotic's performance over time affecting the actual annual fee paid to suppliers. ${ }^{69}$

In Sweden, another subscription model is being piloted by the Swedish Public Health Agency. ${ }^{70}$ Similar to the UK model, this model will also pay suppliers of qualifying clinically-important antibiotics a value-based annual fee in exchange for access to the antibiotic. ${ }^{71}$ Unlike the UK model, however, the Swedish pilot represents a partiallydelinked MER whereby participating suppliers are able to perform volume-based sales while also being guaranteed a minimum annual revenue for qualifying antibiotics, as defined in the subscription contract between the Swedish Public Health Agency and the supplier. ${ }^{70-72}$

Both these models represent novel methods of reimbursement for antibiotics. By combining the MER strategy with a value-based component for reimbursement, these pilot projects may be better equipped than any other implemented incentive to begin addressing the antibiotic pipeline problem. While it is too early to tell how effective these projects will be as data are not yet available, the existence of these projects is certainly an extraordinary step in the right direction.

Lastly, the two hybrid incentives we analyzed both scored 5 points in our assessment, meeting several important framework criteria. The OMA model is unique in that it is the only assessed incentive that would be expected to encourage participation of pharmaceutical companies of all sizes, as it allows funders to share some of the venture risk with the pharmaceutical firm by investing in a drug regardless of where it is in the development pipeline. ${ }^{18}$ However, the OMA model does not promote antibiotic conservation. On the other hand, the ACE model has antibiotic conservation as its primary goal, using conditional performance-based payments to reward innovative antibiotics and drug stewardship in post-market use. ${ }^{18}$ Unfortunately, being a pull-centered incentive strategy, the drawback is that this model would appeal to large pharmaceutical firms much more than to SMEs. ${ }^{18}$

In the next section, a case study using Canada as a country-based example will assess which of the recommended incentive strategies from the articles included in this review could best befit the Canadian landscape.

\section{Applying Incentives in the Canadian Landscape: A Case Study \\ The Canadian Landscape}

In Canada, the health care system, best known as Medicare, is a universal publicly funded system regulated by the federal government and delivered through Canada's 13 provinces and territories. ${ }^{73}$ At present, Canada is the only country with a universal health care system that lacks a national pharmacare program, with prescription drug coverage varying considerably among provinces, resulting in one in five Canadians struggling to afford prescription medicines. ${ }^{74}$ However, a plan to implement a cost-saving national pharmacare program has recently been announced by the Canadian government. ${ }^{74}$ In brief, this plan recommends the creation of a drug agency responsible for assigning and approving drugs to a national formulary (ie, the drugs which will be covered under pharmacare), with the initial list of national formulary drugs set to be available on January $1,2022 .{ }^{74}$ Over the next five years, the national formulary will expand to include drugs beyond essential medicines, including expensive drugs for rare diseases, with the goal of having a full, comprehensive formulary in place by $2027 .^{74}$

When it comes to addressing antibiotic resistance, proposed solutions lack focus on antibiotic innovation, with possible drug development financial incentive models or suggestions remaining largely unexplored. In fact, most reports, awareness platforms, or action plans in Canada $^{14,75-77}$ have largely refrained from suggesting solutions that specifically address the lack of new antibiotics as one of the challenges contributing to the overall threat of antibiotic resistance, although treating drugresistant bacterial infections in the future will become 
increasingly difficult without new antibiotics. So far, the only way that this problem has been addressed in Canada has been by the recent implementation of an expedited regulatory review process for antibiotic drugs that target pathogens from Health Canada's "Pathogen of Interest" list, published in 2018, which contains a list of the pathogens responsible for the most hard-to-treat infections in Canada. $^{78}$

\section{A Path Forward?}

When translating antibiotic incentive recommendations from the literature into the context of a Canadian perspective, there are a couple criteria that are relevant to consider. First, it is likely that the implementation of a financial incentive model in Canada may involve a slow uptake due to the fact that the revitalizing of the antibiotic pipeline is not currently seen as a pressing issue within the national strategy for combatting antibiotic resistance. ${ }^{14}$ Thus, the feasibility of implementation will be of particular importance in deciding an appropriate incentive strategy for implementation in Canada. Furthermore, the composition of Canada's pharmaceutical industry must also be considered when assessing the suitability of different antibiotic incentive strategies for Canada. While some local pharmaceutical companies exist, foreign multinational companies with subsidiaries in Canada represent the majority of Canadian drug sales and R\&D investment. ${ }^{79}$ Despite this, interest in R\&D investment in Canada by multinational companies is relatively low on the global priority list, with Canadian SMEs and contract research organizations carrying out an increasingly large proportion of Canadian $\mathrm{R} \& \mathrm{D}$ activities. ${ }^{79,80}$ In terms of antibiotic R\&D, Canada is not a major global player, as evidenced by the fact that Canadian companies are only developing two of the 32 antibiotics targeting WHO priority pathogens which are currently in clinical development. ${ }^{16}$

Based on our incentive analysis, we recommend that Canada follow in the footsteps of the UK and Sweden by implementing a subscription-based MER which would be accessible to both local and multinational drug developers selling into the Canadian market. While there may be some resistance to the implementation of such an incentive in Canada due to the high associated cost, we argue that investing in this field now will ultimately end up saving taxpayer money which would otherwise be spent on the health burden due to $A B R$ if the status quo is maintained. ${ }^{6,81}$ As per our assessment (Table 4), MERs were highly ranked among analyzed incentive strategies, with fully delinked incentives receiving the highest score and partly delinked incentives being one of the four strategies awarded the next highest score. However, by combining a basic MER strategy with a value-based reimbursement strategy, the subscription-based model addresses the two major weaknesses of a basic MER strategy: an inherent disregard for the antibiotic's level of innovativeness and its performance over time. The value-based reimbursement component of both the UK and Swedish subscription-based models ensures that only antibiotics of sufficient clinical importance receive the reward and calls for the value of the antibiotic's annual subscription fee to be adjusted according to the antibiotic's performance. The UK and Swedish pilot schemes could be used as models to inspire the creation of a similar pull MER incentive strategy in Canada, whereby the government will pay an annual subscription fee to suppliers of qualifying antibiotics. Referring to the details surrounding the implementation of these pilot schemes in other countries will facilitate the design and implementation of a subscription-based MER in Canada that complements, supports, and builds upon existing pull incentive pilot projects. Conversely, most other pull incentive strategies and both hybrid incentive strategies analyzed in this review have not yet been successfully implemented in other countries (Table 4), which may consequently render implementation in Canada more challenging. Beyond feasibility challenges, implementing an incentive that has not yet been implemented anywhere else in the world would result in a less positive effect than the translation of an existing incentive to the Canadian landscape. As ABR is an issue affecting all countries, a solution that contributes to a multinational approach by supporting the work being done in other countries is needed; therefore, a subscription-based MER following an existing model is well-suited.

In terms of whether the UK's fully delinked or Sweden's partially delinked subscription model would be more effective, we posit that Canada would benefit from following the UK's lead in order to implement a similar fully delinked subscription-based MER optimized for the Canadian landscape. Given Canada's early stage of development for its new national pharmacare program, the integration of a similar program could be easier to achieve. A fully delinked MER model is distinguished from a partially delinked model as the former requires the drug developer to agree to not sell or promote the use of their product, with the developer's main revenue stream consisting of the MER, whereas the latter allows the developer to continue selling their product for 


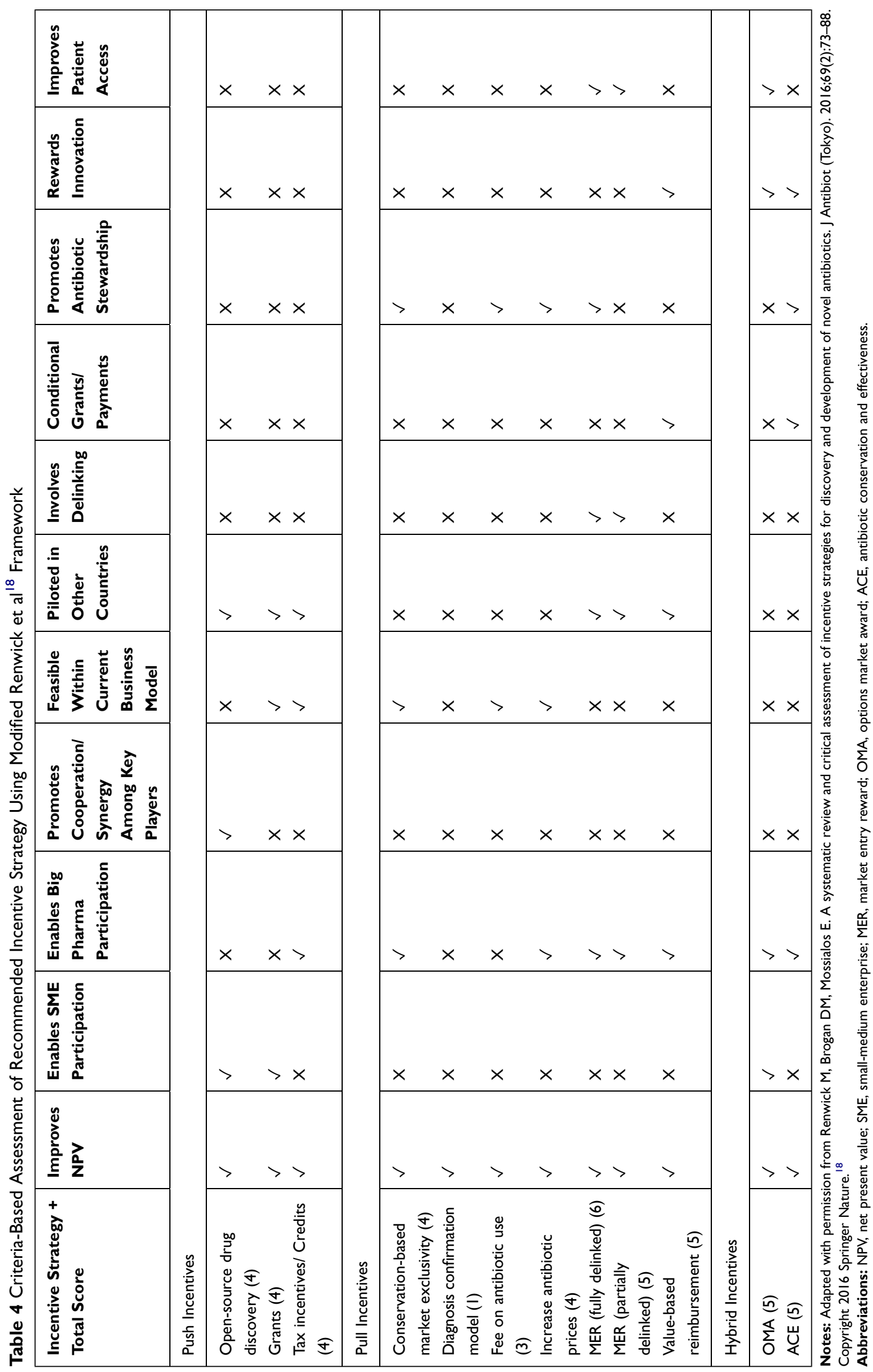


profit and also awards the developer with an MER. ${ }^{37}$ The main advantage of the fully delinked model compared to the partial model is that it completely removes the motivation to maximize unit sales, aligning with antibiotic conservation and stewardship efforts. Additionally, given that more implementation design information and details are publicly available for the UK model at present, it will be easier to apply this pilot incentive model over the Swedish model to the Canadian landscape.

Alternatively, if the Canadian government does not have the political traction or appropriate resources to commit to a pull incentive strategy at this point in time, targeted grants for financing clinical development may also be productive given the considerations of the Canadian landscape. Despite being undervalued by our included articles, with only 10 articles (24\%) suggesting grants as a component of their proposed mix/hybrid incentive model or as a standalone mechanism, we posit that this mechanism is an appropriate way forward in Canada. One advantage of grants is that they have been used as incentives to promote antibiotic research in other countries, such as the Biomedical Advanced Research and Development Authority (BARDA) in the United States (US), among others, which demonstrates that this is a feasible approach to implement in Canada. ${ }^{35}$ The fact that such an incentive could be funded either by the government or by an NGO is also an attractive component, as it gives some flexibility regarding its implementation. Furthermore, this incentive would not radically change the market or pharmaceutical business model; instead, it would simply function to lower R\&D cost for both small and large pharmaceutical companies, thereby encouraging them to develop new antibiotics. While it is true that grants mainly encourage the participation of SMEs over large pharmaceutical firms, ${ }^{18}$ this type of incentive may be particularly well-suited in Canada, where $R \& D$ is being increasingly carried out by Canadian SMEs and contract organizations. ${ }^{79}$ As access to capital is the biggest hurdle to drug commercialization for these Canadian SMEs, ${ }^{79}$ implementing a grant incentive strategy may serve as an important motivator for driving projects forward. These targeted grants should only finance the development of antibiotics for high-priority pathogens for which limited treatment options currently exist, thereby allowing the managing body to control which antibiotics will enter the market, ensuring that future Canadians have access to alternative treatments for high-threat bacterial infections.
Importantly, given the Canadian government's recent commitment to the implementation of a national pharmacare program, we must consider whether pharmacare would impact the suitability or success level of certain financial incentive mechanisms in motivating antibiotic innovativeness. We posit that a possible negative effect of introducing pharmacare could be that systemic changes to the pricing and reimbursement environment may result in drug manufacturing companies becoming even more demotivated to produce innovative antibiotics; however, there is much that is still unknown about how pharmacare will be implemented in Canada and its downstream effects. ${ }^{82}$ If drastically reduced prices are enforced, this would provide Canada with all the more reason to invest in financial incentives as a mitigation measure. The introduction of a national pharmacare program in Canada would render the fully delinked subscription model developed as per the UK's pilot as a particularly suitable mechanism to stimulate substantial innovation, as it will motivate drug manufacturers to develop clinically beneficial antibiotics whilst guaranteeing qualifying manufacturers revenue from successfully marketing such antibiotics. Additionally, it is possible that national pharmacare may bring new challenges pertaining to antibiotic stewardship at the community level, as it would eliminate cost-related barriers to antibiotic access and use; however, implementing an incentive similar to the UK subscription model which fully unlinks product sales from revenue and also considers how well the antibiotic performs as a factor in determining a supplier's actual payment - will significantly counteract this issue.

\section{Conclusion}

As more and more people become infected with hard-totreat, multi-drug resistant infections, having reliable and effective antibiotic drugs will become more important than ever. However, multiple barriers exist that render antibiotic investment an unattractive business endeavor for pharmaceutical companies and novel solutions need to be explored by policymakers to urgently address this lack of innovation.

This systematic review identified 42 articles containing recommendations for solutions for revitalizing the antibiotic pipeline, with the majority advocating for the implementation of mix/hybrid financial incentive models. The lack of consensus regarding the specific design and size of a financial incentive model suggests that there is no one-size-fits-all solution; rather, it seems that some incentive schemes may be more useful for some countries than for others. 
When applying the results of this literature review to a case study of Canada that considers Canada's specific needs, we propose that Canada support ongoing efforts in other countries by implementing a fully delinked subscription-based MER similar to the pilot model that was recently launched in the UK. Following the model laid out by the UK provides Canada with a reference for facilitating implementation, despite the feasibility challenges otherwise associated with fully delinked incentives. Further, the fully delinked model removes the drug manufacturer's desire to maximize revenue from unit sales and the annually adjusted subscription fee ensures that the payment reflects the antibiotic's performance over time. On the other hand, if Canada is unwilling to implement a pull incentive, we also suggest an alternative and less disruptive incentive strategy: grants targeting high-priority pathogens for which there are limited treatment options. Implementing a financial incentive model suited to the Canadian context will be an overdue and crucial step forward for controlling antibiotic resistance and lowering the incidence of death due to drug-resistant infections in Canada as well as around the world.

\section{Acknowledgments}

We wish to thank Dr. Suzanne Hindmarch who provided thoughtful feedback on this manuscript.

\section{Funding}

Sean Hillier is a member of the Globall Health Network (http://global1hn.ca/), supported by a grant from the Canadian Institutes of Health Research (CIHR), Funding Reference No. NGR - 167542. Research findings from these grants do not necessarily reflect the opinions of CIHR.

\section{Disclosure}

The authors report no conflicts of interest in this work.

\section{References}

1. Sinha MS, Kesselheim AS. Regulatory incentives for antibiotic drug development: a review of recent proposals. Bioorg Med Chem. 2016;24(24):6446-6451. doi:10.1016/j.bmc.2016.08.033

2. Office of National Statistics. Causes of death over 100 years. 2017. Available from: https://www.ons.gov.uk/peoplepopulationandcommu nity/birthsdeathsandmarriages/deaths/articles/causesofdeathover100 years/2017-09-18. Accessed April 10, 2020.

3. Jones DS, Podolsky SH, Greene JA. The burden of disease and the changing task of medicine. N Engl J Med. 2012;366(25):2333-2338. doi:10.1056/NEJMp1113569
4. Podolsky SH. The evolving response to antibiotic resistance (1945-2018). Palgrave Commun. 2018;4:1. doi:10.1057/s41599-018-0181-x

5. Aslam B, Wang W, Arshad MI, et al. Antibiotic resistance: a rundown of a global crisis. Infect Drug Resist. 2018;11:1645-1658. doi:10.21 47/IDR.S173867

6. O'Neill J. Tackling drug-resistant infections globally: final report and recommendations. 2016. Available from: https://amr-review.org/. Accessed April 10, 2020.

7. Baraka MA, Alsultan H, Alsalman T, Alaithan H, Islam MA, Alasseri AA. Health care providers' perceptions regarding antimicrobial stewardship programs (AMS) implementation-facilitators and challenges: a cross-sectional study in the Eastern province of Saudi Arabia. Ann Clin Microbiol Antimicrob. 2019;18(1):26. doi:10.1186/ s12941-019-0325-x

8. Bianco A, Papadopoli R, Mascaro V, Pileggi C, Pavia M. Antibiotic prescriptions to adults with acute respiratory tract infections by Italian general practitioners. Infect Drug Resist. 2018;11: 2199-2205. doi:10.2147/IDR.S170349

9. Council of Canadian Academies. When antibiotics fail. 2019. Available from: https://cca-reports.ca/wp-content/uploads/2018/10/ When-Antibiotics-Fail-1.pdf. Accessed April 9, 2020.

10. Dekker ARJ, Verheij TJM, Van Der Velden AW. Inappropriate antibiotic prescription for respiratory tract indications: most prominent in adult patients. Fam Pract. 2015;32(4):401-407. doi:10.1093/fampra/ cmv019

11. Knight GM, McQuaid CF, Dodd PJ, Houben RMGJ. Global burden of latent multidrug-resistant tuberculosis: trends and estimates based on mathematical modelling. Lancet Infect Dis. 2019;19(8):903-912. doi:10.1016/S1473-3099(19)30307-X

12. Abelenda-Alonso G, Padullés A, Rombauts A, et al. Antibiotic prescription during the COVID-19 pandemic: a biphasic pattern. Infect Control Hosp Epidemiol. 2020;41(11):1371-1372. doi:10.1017/ice.2020.381

13. World Health Organization. Global action plan on antimicrobial resistance. 2015. Available from: https://www.who.int/antimicrobialresistance/global-action-plan/en/. Accessed March 14, 2020.

14. Government of Canada. Tackling antimicrobial resistance and antimicrobial use: a pan-Canadian framework for action. 2017. Available from: https://www.canada.ca/en/health-canada/services/publications/ drugs-health-products/tackling-antimicrobial-resistance-use-pancanadian-framework-action.html. Accessed April 9, 2020.

15. Sabtu N, Enoch DA, Brown NM. Antibiotic resistance: what, why, where, when and how? Br Med Bull. 2015;116(1):105-113. doi:10.1093/bmb/ldv041

16. World Health Organization. 2019 antibacterial agents in clinical development: an analysis of the antibacterial clinical development pipeline. 2019. Available from: https://www.who.int/publications/i/ item/9789240000193. Accessed April 15, 2020.

17. Outterson K, Powers JH, Daniel GW, McClellan MB. Repairing the broken market for antibiotic innovation. Health Aff. 2015;34 (2):277-285. doi:10.1377/hlthaff.2014.1003

18. Renwick M, Brogan DM, Mossialos E. A systematic review and critical assessment of incentive strategies for discovery and development of novel antibiotics. J Antibiot (Tokyo). 2016;69(2):73-88. doi:10.1038/ja.2015.98

19. Batista H, Byrski D, Lamping M, Romandini R. IP-based incentives against antimicrobial crisis: a European perspective. Int Rev Intellect Prop Compet Law. 2019;50:30-76. doi:10.1007/s40319-018-00782-w

20. Talbot GH, Jezek A, Murray BE, et al. The infectious diseases society of America's $10 \times$ '20 initiative (10 new systemic antibacterial agents US Food and Drug Administration approved by 2020): is $20 \times$ '20 a possibility? Clin Infect Dis. 2019;69(1):1-11. doi:10.1093/ $\mathrm{cid} / \mathrm{ciz} 089$

21. Renwick M, Mossialos E. What are the economic barriers of antibiotic R\&D and how can we overcome them? Expert Opin Drug Discov. 2018;13(10):889-892. doi:10.1080/17460441.2018.1515908 
22. Brogan DM, Mossialos E. Incentives for new antibiotics: the Options Market for Antibiotics (OMA) model. Global Health. 2013;9 (58):1-10. doi:10.1186/1744-8603-9-58

23. Darrow J, Sinha M, Kesselheim A. When markets fail: patents and infectious disease products. Food Drug Law J. 2018;73(3):361-382. doi: $10.2307 / 26661184$

24. Chit A, Grootendorst P. Policy to encourage the development of antimicrobials. Int J Health Gov. 2018;23(2):101-110. doi:10.1108/ IJHG-12-2017-0062

25. Hollis A, Maybarduk P. Antibiotic resistance is a tragedy of the commons that necessitates global cooperation. J Law Med Ethics. 2015;43:33-37. doi:10.1111/jlme.12272

26. Anderson M, Clift C, Schulze K, et al. Averting the AMR crisis: what are the avenues for policy action for countries in Europe? 2019. Available from: https://www.oecd.org/health/health-systems /Averting-the-AMR-crisis-Policy-Brief-32-March-2019.PDF. Accessed April 10, 2020.

27. Klein EY, Van Boeckel TP, Martinez EM, et al. Global increase and geographic convergence in antibiotic consumption between 2000 and 2015. Proc Natl Acad Sci U S A. 2018;115(15):E3463-E3470. doi:10.1073/pnas.1717295115

28. Årdal C, Røttingen J-A, Opalska A, Van Hengel AJ, Larsen J. Pull incentives for antibacterial drug development: an analysis by the transatlantic task force on antimicrobial resistance. Clin Infect Dis. 2017;65(8):1378-1382. doi:10.1093/cid/cix526

29. Luepke KH, Suda KJ, Boucher H, et al. Past, present, and future of antibacterial economics: increasing bacterial resistance, limited antibiotic pipeline, and societal implications. Pharmacotherapy. 2017;37 (1):71-84. doi:10.1002/phar.1868

30. Finland M, Kirby W, Chabbert Y, et al. Round table: are new antibiotics needed? Antimicrob Agents Chemother. 1965;5:1107-1114.

31. Ciabuschi F, Baraldi E, Lindahl O, Callegari S. Supporting innovation against the threat of antibiotic resistance: exploring the impact of public incentives on firm performance and entrepreneurial orientation. J Bus Res. 2019;112:271-280. doi:10.1016/j.jbusres. 2019.12.021

32. So AD, Shah TA. New business models for antibiotic innovation. Ups J Med Sci. 2014;119(2):176-180. doi:10.3109/03009734.2014.898717

33. Moher D, Liberati A, Tetzlaff J, Altman DG. Preferred reporting items for systematic reviews and meta-analyses: the PRISMA statement. PLoS Med. 2009;6(7):e1000097. doi:10.1371/journal. pmed.1000097

34. Baraldi E, Ciabuschi F, Leach R, Morel C, Waluszewski A. Exploring the obstacles to implementing economic mechanisms to stimulate antibiotic research and development: a multi-actor and system-level analysis. Am J Law Med. 2016;42(2-3):451-486. doi:10.1177/ 0098858816658276

35. Savic M, Årdal C. A grant framework as a push incentive to stimulate research and development of new antibiotics. J Law Med Ethics. 2018;46:9-24. doi:10.1177/1073110518782911

36. Brogan DM, Mossialos E. Systems, not pills: the options market for antibiotics seeks to rejuvenate the antibiotic pipeline. Soc Sci Med. 2016;151:167-172. doi:10.1016/j.socscimed.2016.01.005

37. Sciarretta K, Røttingen J-A, Opalska A, Van Hengel AJ, Larsen J. Economic incentives for antibacterial drug development: literature review and considerations from the transatlantic task force on antimicrobial resistance. Clin Infect Dis. 2016;63(11):1470-1474. doi:10.1093/cid/ciw593

38. Morel C, Edwards SE. Encouraging sustainable use of antibiotics: a commentary on the DRIVE-AB recommended innovation incentives. J Law Med Ethics. 2018;46:75-80. doi:10.1177/107311 0518782918

39. Daniel GW, Schneider M, Lopez MH, McClellan MB. Implementation of a market entry reward within the United States. J Law Med Ethics. 2018;46:50-58. doi:10.1177/1073110 518782915
40. Hojgard S. Antibiotic resistance - why is the problem so difficult to solve? Infect Ecol Epidemiol. 2012;2(1):1-7. doi:10.3402/iee.v2i0.18165

41. Kesselheim AS, Outterson K. Fighting antibiotic resistance: marrying new financial incentives to meeting public health goals. Health Aff. 2010;29(9):1689-1696. doi:10.1377/hlthaff.2009.0439

42. Kesselheim AS, Outterson K. Improving antibiotic markets for long-term sustainability. Yale J Health Policy Law Ethics. 2011;11(1):101-167.

43. Laxminarayan R, Powers JH. Antibacterial R\&D incentives. Nat Rev Drug Discov. 2011;10(10):727-728. doi:10.1038/nrd3560

44. Mckellar MR, Fendrick AM. Innovation of novel antibiotics: an economic perspective. Clin Infect Dis. 2014;59(suppl_3):S104S107. doi:10.1093/cid/ciu530

45. Okhravi C, Callegari S, McKeever S, et al. Simulating market entry rewards for antibiotics development. $J$ Law Med Ethics. 2018;46:32-42. doi:10.1177/1073110518782913

46. Simpkin VL, Renwick MJ, Kelly R, Mossialos E. Incentivising innovation in antibiotic drug discovery and development: progress, challenges and next steps. $J$ Antibiot (Tokyo). 2017;70(12): 1087-1096. doi:10.1038/ja.2017.124

47. Towse A, Hoyle CK, Goodall J, Hirsch M, Mestre-Ferrandiz J, Rex JH. Time for a change in how new antibiotics are reimbursed: development of an insurance framework for funding new antibiotics based on a policy of risk mitigation. Health Policy (New York). 2017;121(10):1025-1030. doi:10.1016/j.healthpol. 2017.07.011

48. Towse A, Sharma P. Incentives for R\&D for new antimicrobial drugs. Int JEcon Bus. 2011;18(2):331-350. doi:10.1080/13571516.2011.584434

49. Årdal C, Johnsen J, Johansen K. Designing a delinked incentive for critical antibiotics: lessons from Norway. J Law Med Ethics. 2018;46:43-49. doi:10.1177/1073110518782914

50. Daniel GW, Schneider M, McClellan MB. Addressing antimicrobial resistance and stewardship: the Priority Antimicrobial Value and Entry (PAVE) award. JAMA. 2017;318(12):1103-1104. doi:10.1001/ jama.2017.10164

51. Bhatti T, Lum K, Holland S, Sassman S, Findlay D, Outterson K. A perspective on incentives for novel inpatient antibiotics: no one-size-fits-all. J Law Med Ethics. 2018;46:59-65. doi:10.1177/ 1073110518782916

52. Brogan DM, Mossialos E. A critical analysis of the review on antimicrobial resistance report and the infectious disease financing facility. Global Health. 2016;12(8). doi:10.1186/s12992-016-0147-y

53. Livermore DM. The 2018 Garrod lecture: preparing for the black swans of resistance. J Antimicrob Chemother. 2018;73(11):29 07-2915. doi:10.1093/jac/dky265

54. Lum K, Bhatti T, Holland S, Guthrie M, Sassman S. Diagnosis confirmation model: a value-based pricing model for inpatient novel antibiotics. J Law Med Ethics. 2018;46(1_suppl):66-74. doi:10.1177/ 1073110518782917

55. Outterson K, Rex JH. Evaluating for-profit public benefit corporations as an additional structure for antibiotic development and commercialization. Transl Res. 2020;220:182-190. doi:10.1016/j. trs1.2020.02.006

56. Rex JH, Outterson K. Antibiotic reimbursement in a model delinked from sales: a benchmark-based worldwide approach. Lancet Infect Dis. 2016;16(4):500-505. doi:10.1016/S14733099(15)00500-9

57. Singer AC, Kirchhelle C, Roberts AP. Reinventing the antimicrobial pipeline in response to the global crisis of antimicrobial-resistant infections. F1000Research. 2019;8:238. doi:10.12688/f1000research. 18302.1

58. Spellberg B. The future of antibiotics. Crit Care. 2014;18(3):228 doi:10.1186/cc13948

59. Theuretzbacher U, Årdal C, Harbarth S. Linking sustainable use policies to novel economic incentives to stimulate antibiotic research and development. Infect Dis Rep. 2017;9(1):28-31. doi:10.4081/ idr.2017.6836 
60. Vågsholm I, Höjgård S. Antimicrobial sensitivity: a natural resource to be protected by a pigouvian tax? Prev Vet Med. 2010;96:9-18. doi:10.1016/j.prevetmed.2010.05.003

61. Rome BN, Kesselheim AS. Transferrable market exclusivity extensions to promote antibiotic development: an economic analysis. Clin Infect Dis. 2019. doi:10.1093/cid/ciz1039

62. James JE. Can public financing of the private sector defeat antimicrobial resistance? J Public Health. 2018;41(2):422-426. doi:10.1093/pubmed/fdy116

63. The Chatham House. Towards a new global business model for antibiotics: delinking revenues from sales. 2015. Available from: https://www. chathamhouse.org/sites/default/files/field/field_document/ 20151009NewBusinessModelAntibioticsCliftGopinathanMorelOutterso nRottingenSo.pdf. Accessed December 2, 2020.

64. Babic M, Heemskerk E, Fichtner J. Who is more powerful - states or corporations? Conversation. 2018.

65. Rubin IS. The politics of public budgets. In: Rubin IS, ed. The Politics of Public Budgeting: Getting and Spending, Borrowing and Balancing. CQ Press; 2016:1-37.

66. Grace C, Kyle M. Comparative advantages of push and pull incentives for technology development: lessons for neglected disease technology development. 2009:147-151. Available from: http://www. margaretkyle.net/PushPull.pdf. Accessed January 2, 2021.

67. Renwick MJ, Simpkin V, Mossialos E, Schippers E. Targeting innovation in antibiotic drug discovery and development. 2016. Available from: https://www.euro.who.int/_ data/assets/pdf_file/0003/315309/Targetinginnovation-antibiotic-drug-d-and-d-2016.pdf. Accessed April 9, 2020.

68. Shlaes DM. The economic conundrum for antibacterial drugs. Antimicrob Agents Chemother. 2020;64(1):1-7. doi:10.1128/AAC.02057-19

69. National Institute for Health and Care Excellence, National Health Service. Developing and testing innovative models for the evaluation and purchase of antimicrobials: subscription-based payment model. 2020. Available from: https://amr.solutions/wp-content/uploads/2020/ 03/2020-03-25-NHS-AMR-Market-Engagement-Briefing-Final.pdf. Accessed December 6, 2020.

70. Public Health Agency of Sweden. Folkhälsomyndigheten utvärderar ny ersättningsmodell för viktiga antibiotika. 2019. Available from: https://www.folkhalsomyndigheten.se/nyheter-och-press/nyhetsarkiv/ 2019/juni/folkhalsomyndigheten-utvarderar-ny-ersattningsmodell-for -viktiga-antibiotika/. Accessed December 6, 2020.

71. Public Health Agency of Sweden. Analys Av Förutsättningar För Att Testa En Ny Ersättningsmodell För Antibiotika. 2016. Available from: https://www.folkhalsomyndigheten.se/publicerat-material/publi kationsarkiv/a/analys-av-forutsattningar-for-att-testa-en-nyersattningsmodell-for-antibiotika/. Accessed December 6, 2020.

72. Rex JH. Sweden to test an access-focused model for new antibiotics: contracting for availability. 2020. Available from: https://amr.solu tions/2020/03/16/sweden-to-test-an-access-focused-model-for-newantibiotics-contracting-for-availability/. Accessed December 6, 2020.
73. Government of Canada. Canada's health care system. 2016. Available from: https:/www.canada.ca/en/health-canada/services/canada-health -care-system.html. Accessed October 10, 2020.

74. Government of Canada. A prescription for Canada: achieving pharmacare for all. 2019. Available from: https://www.canada.ca/en/ health-canada/corporate/about-health-canada/public-engagement /external-advisory-bodies/implementation-national-pharmacare/finalreport.html. Accessed October 10, 2020.

75. Public Health Agency of Canada. Canadian antimicrobial resistance surveillance system report. 2020. Available from: https://www. canada.ca/content/dam/hc-sc/documents/services/drugs-healthproducts/canadian-antimicrobial-resistance-surveillance-system -2020-report/CARSS-2020-report-2020-eng.pdf. Accessed July 24, 2020.

76. Government of Canada. About antibiotic resistance: preserving antibiotics now and in the future. 2019. Available from: https://www. canada.ca/en/public-health/corporate/publications/chief-public-health -officer-reports-state-public-health-canada/preserving-antibiotics /about-antibiotic-resistance.html. Accessed November 21, 2019

77. Public Health Agency of Canada. Federal action plan on antimicrobial resistance and use in Canada. 2015. Available from: https:/www. canada.ca/en/health-canada/services/publications/drugs-healthproducts/federal-action-plan-antimicrobial-resistance-canada.html. Accessed April 9, 2020.

78. Government of Canada. Notice - health Canada's efforts to support innovative human therapeutic products to combat antimicrobial resistance. 2018. Available from: https://www.canada.ca/en/health-canada /programs/consultation-proposed-pathogens-interest-list/noticeefforts-combat-antimicrobial-resistance.html. Accessed November $21,2019$.

79. Government of Canada. Canada's pharmaceutical industry and prospects. 2013. Available from: https://www.ic.gc.ca/eic/site/lsg-pdsv. nsf/eng/hn01768.html. Accessed December 6, 2020.

80. Government of Canada. Pharmaceutical industry profile. 2019. Available from: https://www.ic.gc.ca/eic/site/lsg-pdsv.nsf/eng/h hn01703.html. Accessed December 6, 2020.

81. Sharma P, Towse A. New drugs to tackle antimicrobial resistance: analysis of EU policy options; 2010. Available from: https://www. ohe.org/publications/new-drugs-tackle-antimicrobial-resistance-eupolicy-options. Accessed April 9, 2020.

82. Rawson NSB. National pharmacare in Canada: equality or equity, accessibility or affordability. Int J Health Policy Manag. 2020;9 (12):524-527. doi:10.15171/ijhpm.2019.146
Infection and Drug Resistance

\section{Publish your work in this journal}

Infection and Drug Resistance is an international, peer-reviewed openaccess journal that focuses on the optimal treatment of infection (bacterial, fungal and viral) and the development and institution of preventive strategies to minimize the development and spread of resistance. The journal is specifically concerned with the epidemiology of antibiotic resistance and the mechanisms of resistance development and diffusion in both hospitals and the community. The manuscript management system is completely online and includes a very quick and fair peerreview system, which is all easy to use. Visit http://www.dovepress.com/ testimonials.php to read real quotes from published authors. 